\title{
Clinical-statistical study on the frequency and etiological factors of gingival hyperplasia
}

\author{
Vlad Grigore ${ }^{1}$, Alina Ormenisan ${ }^{1}$, Maria Damasaru ${ }^{2}$, Irina Grecu-Maresal ${ }^{3}$, \\ Haj Isam Osman", Dorin Cocos', Mariana Pacurar ${ }^{2}$ \\ ${ }^{1}$ OMF Surgery, "G.E Palade" UMFST, Tg. Mures, Romania \\ ${ }^{2}$ Orthodontics, "G.E Palade" UMFST, Tg. Mures, Romania \\ ${ }^{3}$ Orthodontics and Dentofacial Orthopedics, St. Gallen, Germany \\ ${ }^{4}$ Faculty of Dentistry, "G.E Palade" UMFST, Tg. Mures, Romania
}

\begin{abstract}
Introduction. Gum hyperplasia is clinically translated by growth in gum size, edema and bleeding (over-normal bags). The gum may be thin or fibrous, firm (in pseudotumor forms). In the absence of proper treatment, it will be associated with the bone resorption of the alveolar process, leading to different degrees of dental mobility. Purpose. Through this clinical-statistical study, we aim to analyze patients diagnosed with gum hyperplasia by age, gender, type of gum hyperplasia, etiology and localization. Also, by observing in surgical practice more and more cases of gum hyperplasia in patients with orthodontic treatment, through this clinical-statistical study, we aim to quantify the incidence of gingival hyperplasia in orthodontic treatments carriers and its distribution by gender. Material and method. The study is retrospective type, performed on 172 patients with the diagnosis of gum hyperplasia (K06.1), treated in the Oro-maxillo-facial surgery Clinic in Targu Mures, during Jan.2015-march 2021. Hypocrate concept 3 was used to access patient observation sheets.

Results and discussions. Analyzing the descriptive statistical data of this retrospective clinical-statistical study, it is observed that the average age of the subjects is 58 years, the distribution by sex favors the female gender ( $59 \%)$, generally occurs in adults, has affinity for the right hemimaxilla, approx. $25 \%$ of patients have gingival hyperplastic lesions caused by orthodontic appliances and mobile/mobilizable prostheses. These types of lesions represent a ratio of 2/1 in favor of females, which indicates that the aesthetic requirements for females are much higher compared to males. Also, interpreting, from a medical point of view, the statistical conclusions of this study, we find that the patient's gender does not influence the location and appearance of the hyperplasic lesion, instead the age of the patients influences the occurrence of the hyperplastic lesion.

Conclusion. Orthodontic therapy should be indicated after a correct evaluation of periodontal tissues, quantification of periodontal indices and detection of risk factors.
\end{abstract}

Keywords: hyperplasia, etiology, localization, orthodontic appliance, periodontal

\section{INTRODUCTION}

Gingival hyperplasia is characterized by slow and progressive growth of gum, which partially or totally covers the crown of the tooth. Gum hyperplasia is clinically translated into growth in gum size, edema and bleeding at the touch, so-called supracrustal bags (1).

The gum may be thin or fibrous, firm (in pseudotumor forms). In the absence of proper treatment, it will be associated with the bone resorption of the alveolar process, leading to different degrees of dental mobility. Many specialist studies (4) highlight the increased frequency of gum hyperplasia (growth in parenchymal cells, not in volume), with a multitude of local and general etiological factors, the mechanism of production not being completely elucidated. The interaction of several factors (genetic, hormonal, medicinal, TNF growth factor, neoplastic) was quantified, except orthodontic therapy and its role in the production of gum hyperplasia $(2,3)$. 
Usually, it occurs at a single root surface, most common, at the buccal aspect $(4,6)$. The appearance of gingival hyperplasia following orthodontic treatment is a controversial study both in the specialty periodontal literature, and in the orthodontic literature, in what regards the intensity and direction of the forces and of gingival biotype $(5,7]$. Apart from the unsatisfactory aesthetic effect, the gingival hyperplasia leads to dental sensitivity, increases the risk of tooth decay, blocking the maintenance of a satisfactory hygiene (8).

\section{PURPOSE}

We aim to analyze patients diagnosed with gingival hyperplasia by age, gender, type of hyperplasia, etiology and location. Also, by observing in surgical practice more and more cases of gum hyperplasia in patients with orthodontic treatment, through this clinical-statistical study, we aim to quantify the incidence of gingival hyperplasia in patients with orthodontic treatment and its distribution by gender.

\section{MATERIAL AND METHOD}

The study is retrospective type, performed on 172 patients with the diagnosis of gingival hyperplasia (K06.1), treated in the Oro-maxillo-facial surgery Clinic in Targu Mures, during January 2015-March 2021. Hypocrate concept 3 was used to access patient observation sheets.

The statistical analysis includes descriptive statistical elements (frequency, percentage, confidence interval $(95 \%)$ the average, median, standard deviation) and inferential statistical elements. The Shapiro-Wilk test was applied to determine the distribution of the analyzed data series. For comparison of medians, the Mann-Whitney test was applied. The square Chi test was applied to determine the association between qualitative variables. The selected threshold for $p$ value was 0.05 . The statistical analysis was performed using the trial version of GraphPad Prism.

The approval of Medical Ethics Commission for the Clinical Study of the Medicine within SCJU Târgu Mureș (no. Ad 5245 from 19.02.2021) was obtained.

\section{RESULTS}

The table 1 shows that the age of the patients covered by the study is between 3 and 92 years with an average age of approximately 58 years.
TABLE 1. The age of the patients

\begin{tabular}{|l|l|c|c|c|}
\hline & $\begin{array}{l}\text { The average } \pm \\
\text { standard deviation }\end{array}$ & Median & Minimum & Maximum \\
\hline Age & $58.14 \pm 19.99$ & 64.00 & 3.00 & 92.00 \\
\hline
\end{tabular}

TABLE 2. Patients distribution by gender

\begin{tabular}{|l|c|c|l|}
\hline & Frequency & Percent & $\begin{array}{l}\text { Confidence interval } \\
\mathbf{9 5 \%}\end{array}$ \\
\hline Females & 101 & $58.72 \%$ & $50.98 \%-66.16 \%$ \\
\hline Males & 71 & $41.28 \%$ & $33.84 \%-49.02 \%$ \\
\hline Total & 172 & $100 \%$ & \\
\hline
\end{tabular}

As regards gender distribution, it is noted that females represent a proportion of around. 59\% of cases, compared to males which represents approx. $41 \%$ of cases (table 2 , figure 1 ).

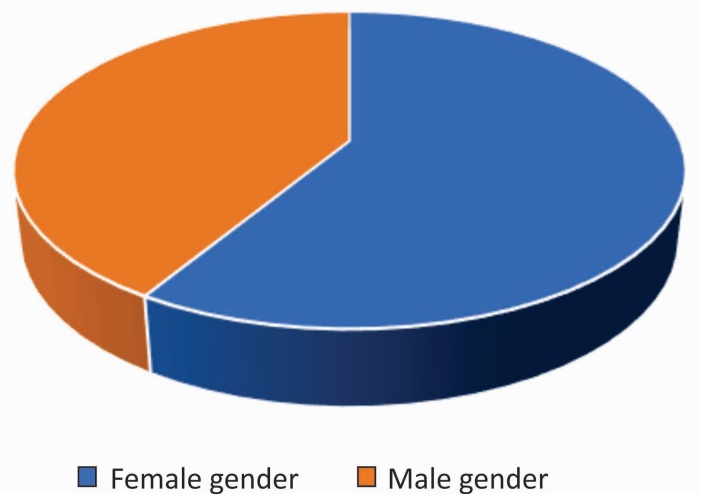

FIGURE 1. Patients distribution by gender

From the point of view of the type of gum hyperplasia, it is observed that the rarest typology of gum hyperplasia recorded in this study is gingival fibromatosis or gingival elephantiasis, followed by the euploids class (figure 2).

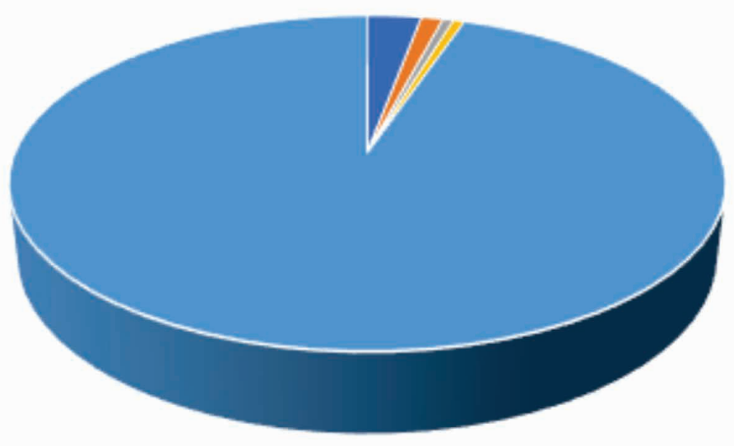

$\begin{array}{ll}\square \text { Epulis } & \square \text { Epulis fissuratum } \\ \square \text { Epulis granulomatosa } & \square \text { Gum fibromatosis } \\ \square \text { Gum hyperplasia } & \end{array}$

FIGURE 2. Types of gum hyperplasia 
TABLE 3. Etiological factors of gingival hyperplasia

\begin{tabular}{|l|r|r|r|}
\hline \multicolumn{1}{|c|}{ Etiology } & Frequency & Percent & $\begin{array}{l}\text { Confidence } \\
\text { interval 95\% }\end{array}$ \\
\hline $\begin{array}{l}\text { Orthodontic } \\
\text { treatment }\end{array}$ & 24 & $13.95 \%$ & $9.15 \%-20.05 \%$ \\
\hline Local irritant factor & 122 & $70.93 \%$ & $63.53 \%-77.59 \%$ \\
\hline Genetic & 1 & $0.58 \%$ & $0.01 \%-3.20 \%$ \\
\hline Eruptive hyperplasia & 1 & $0.58 \%$ & $0,01 \%-3,20 \%$ \\
\hline Decubitus injury & 20 & $11.63 \%$ & $7.25 \%-17.39 \%$ \\
\hline Recurrent & 2 & $1.16 \%$ & $0.14 \%-4.14 \%$ \\
\hline $\begin{array}{l}\text { Chronic treatment } \\
\text { with immunosup- } \\
\text { pressants }\end{array}$ & 1 & $0.58 \%$ & $0.01 \%-3.20 \%$ \\
\hline Pregnancy tumor & 1 & $0.58 \%$ & $0.01 \%-3.20 \%$ \\
\hline Total & 172 & $100.00 \%$ & \\
\hline
\end{tabular}

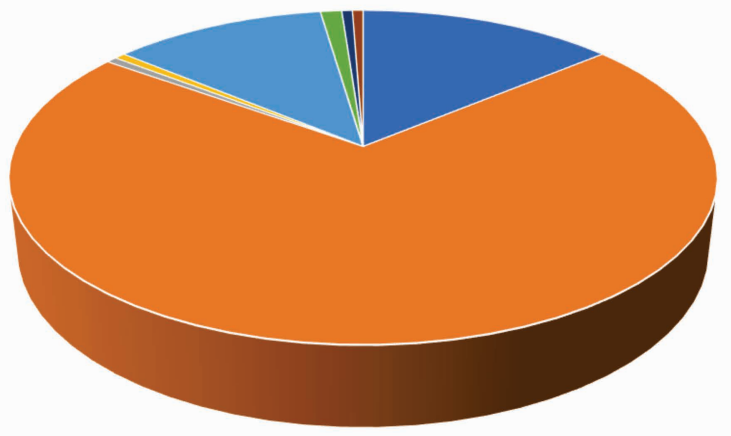

$\square$ Orthodontic treatment

$\square$ Genetic

$\square$ Decubitus injury

- Chronic treatment with immunosuppressants

FIGURE 3. Etiological factors of gum hyperplasia

As regards the quantification of etiological factors, it is noted that a significant percentage of $t$ gum hyperplasia is produced by orthodontic treatment, approximately $14 \%$ of cases. Also, a significant percentage of approx. $12 \%$ of cases are decubitus lesions caused by incorrect adaptation of mobile prostheses. A small percentage is represented by the relapse, systematic and genetic etiological factors (table 3 , figure 3 ).

TABLE 4. Location of the hyperplasic lesions

\begin{tabular}{|l|r|r|r|}
\hline \multicolumn{1}{|c|}{ Location } & Frequency & Percent & $\begin{array}{l}\text { Confidence } \\
\text { interval 95\% }\end{array}$ \\
\hline Bimaxillary & 5 & $2.91 \%$ & $0.95 \%-6.65 \%$ \\
\hline Mandible & 3 & $1.74 \%$ & $0.36 \%-5.01 \%$ \\
\hline Mandible right side & 28 & $16.28 \%$ & $11.10 \%-22.66 \%$ \\
\hline Mandible left side & 44 & $25.58 \%$ & $19.24 \%-32.78 \%$ \\
\hline Maxillary right side & 54 & $31.40 \%$ & $24.55 \%-38.90 \%$ \\
\hline Maxillary left side & 38 & $22.09 \%$ & $16.13 \%-29.04 \%$ \\
\hline Total & 172 & $100.00 \%$ & \\
\hline
\end{tabular}

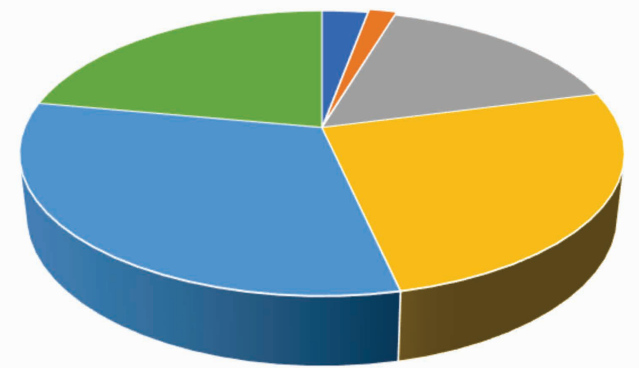

$\begin{array}{lll}\square \text { Bimaxillary } & \square \text { Mandible } & \square \text { Mandible right side } \\ \square \text { Mandible left } & \square \text { Maxillary right } & \square \text { Maxillary left side } \\ \text { side } & \text { side }\end{array}$

FIGURE 4. Location of the hyperplasic lesions

As for the location of the lesions, this study shows that the gingival hyperplasia has the highest affinity for the right side of maxillary, followed by the left side of mandible and maxillary (table 4, figure 4).

TABLE 5. Types of gum hyperplasia

\begin{tabular}{|l|r|r|}
\hline \multicolumn{1}{|c|}{ Type of hyperplasia } & Females & Males \\
\hline Epulis & 2 & 3 \\
\hline Epulis fissuratum & 2 & 0 \\
\hline Epulis granulomatosa & 0 & 1 \\
\hline Gum fibromatosis & 1 & 0 \\
\hline Gingival hyperplasia & 96 & 67 \\
\hline Total & 101 & 71 \\
\hline
\end{tabular}

From the point of view of the gender distribution of the type of gingival hyperplasia, we note that lesions in the epulis class are distributed by gender approximately equal (table 5, figure 5).

TABLE 6. Etiological factors by gender

\begin{tabular}{|l|r|r|}
\hline \multicolumn{1}{|c|}{ Etiology } & Females & Males \\
\hline Orthodontic treatment & 17 & 7 \\
\hline Local irritant factor & 68 & 54 \\
\hline Genetic & 1 & 0 \\
\hline Eruptive hyperplasia & 0 & 1 \\
\hline Decubitus lesion & 13 & 7 \\
\hline Recurrent & 1 & 1 \\
\hline $\begin{array}{l}\text { Chronic treatment with } \\
\text { immunosuppressants }\end{array}$ & 0 & 1 \\
\hline Pregnancy tumor & 1 & 0 \\
\hline Total & 101 & 71 \\
\hline
\end{tabular}




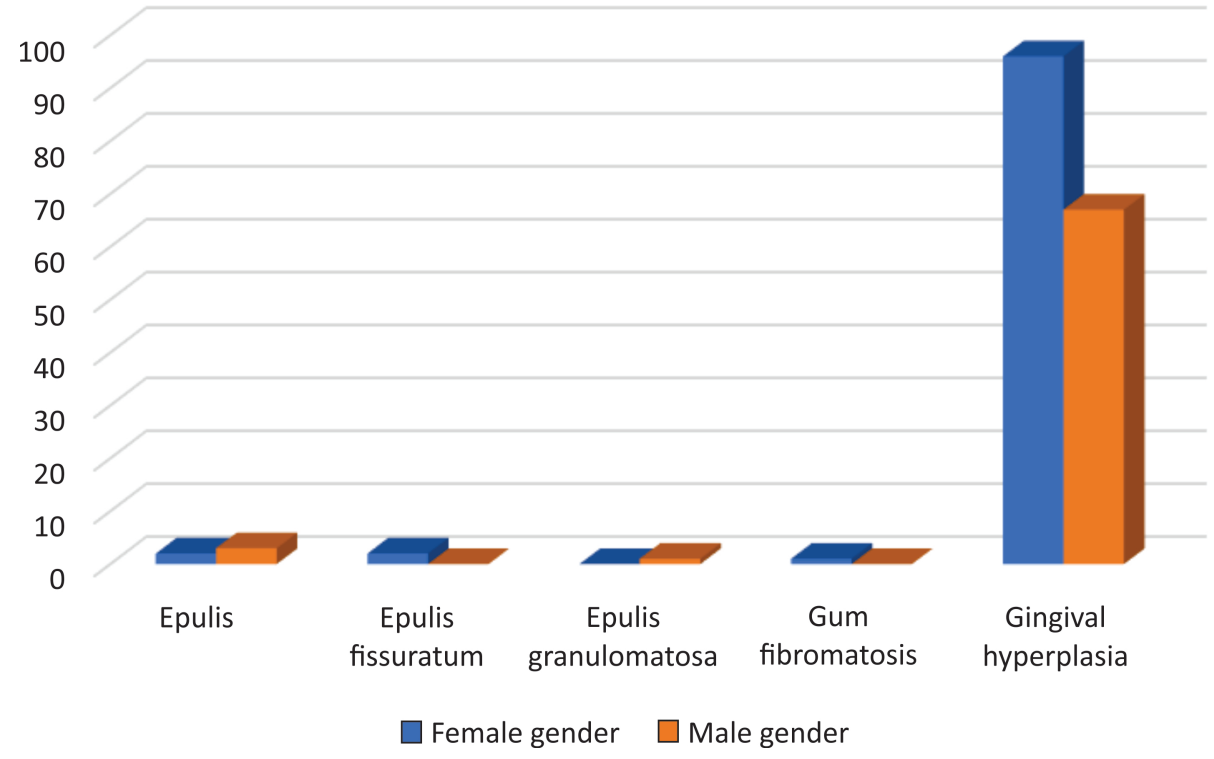

FIGURE 5. Types distribution by gender

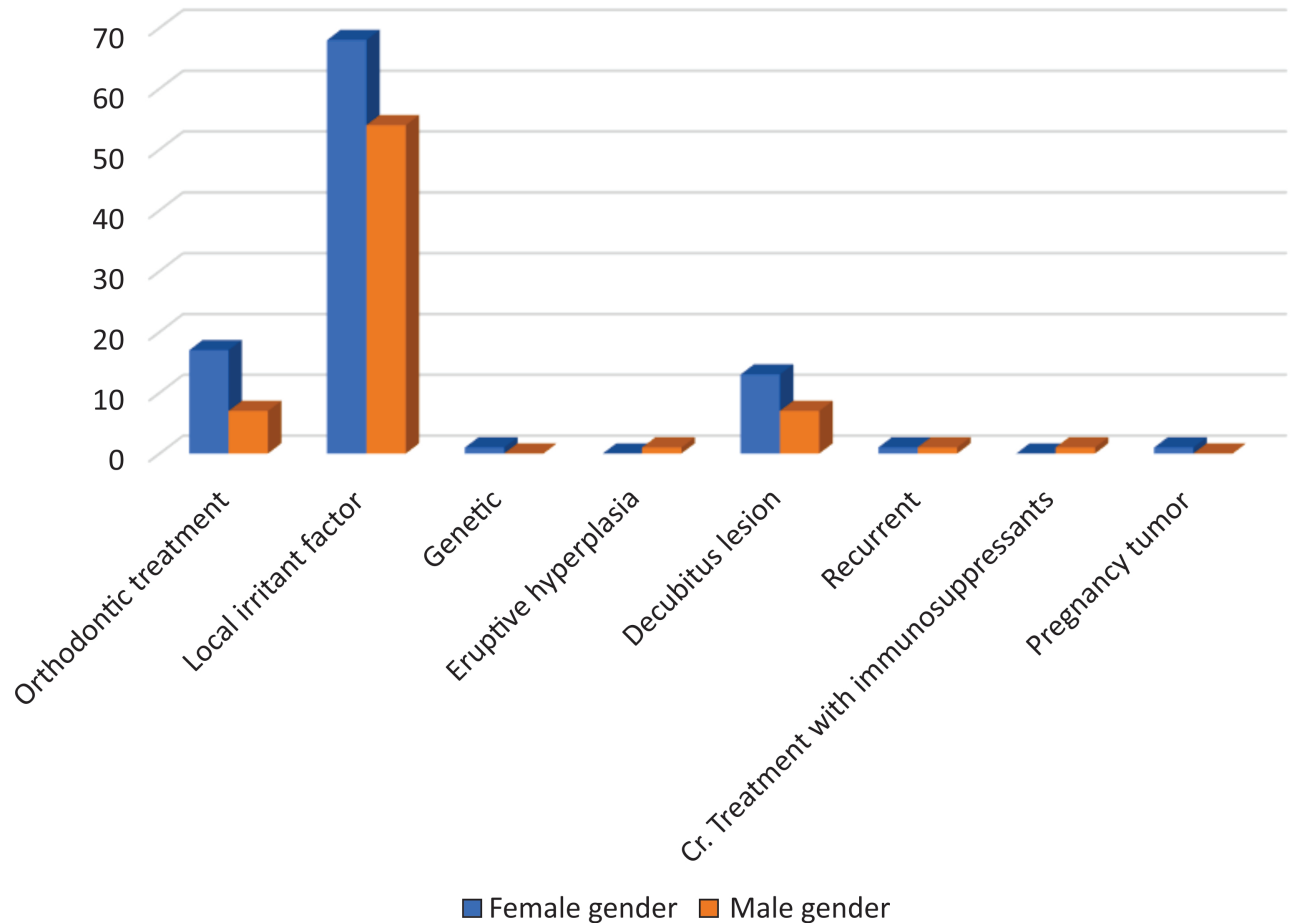

FIGURE 6. Etiological factors by gender

From an etiology point of view of hyperplasia lesions, their gender distribution shows that lesions produced by orthodontic treatment and decubitus represent approx. $2 / 1$ in favor of the females. This shows that the esthetic demands of the females are much higher compared to the males (table 6, figure 6).
TABLE 7. Location of the hyperplasic lesion by gender

\begin{tabular}{|c|c|c|c|}
\hline Location & Females & Males & P value \\
\hline Bimaxillary & 3 & 2 & \multirow{7}{*}{0.9974} \\
\hline Mandible & 2 & 1 & \\
\hline Mandible right side & 16 & 12 & \\
\hline Mandible left side & 25 & 19 & \\
\hline Maxillary right side & 33 & 21 & \\
\hline Maxillary left side & 22 & 16 & \\
\hline Total & 101 & 71 & \\
\hline
\end{tabular}




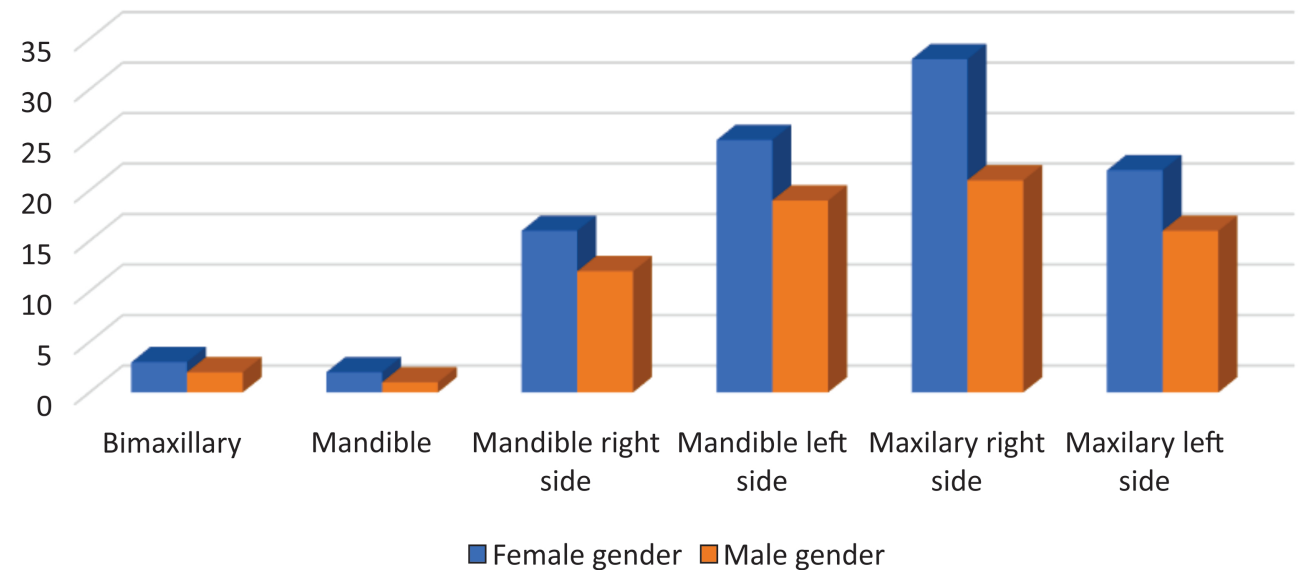

FIGURE 7. Location by gender

The Chi-square test, $\mathrm{p}>0.05$, showed that there is no statistically significant association between gender and the location of the gingival hyperplastic lesion. From a medical point of view, we can hypothesize that regarding this clinical-statistical study, the patient's gender does not influence the location of the hyperplasic lesion.

According to location by gender, we have noticed that most of cases are on maxillary right side (52 cases), followed by mandible left side (43 cases) (table 7, figure 7).

TABLE 8. Location of common type of gum hyperplasia

\begin{tabular}{|l|r|}
\hline \multicolumn{1}{|c|}{ Location } & $\begin{array}{l}\text { Common type of gum } \\
\text { hyperplasia }\end{array}$ \\
\hline Bimaxillary & 5 \\
\hline Mandible & 3 \\
\hline Mandible right side & 25 \\
\hline Mandible left side & 43 \\
\hline Maxillary right side & 52 \\
\hline Maxillary left side & 35 \\
\hline Total & 163 \\
\hline
\end{tabular}

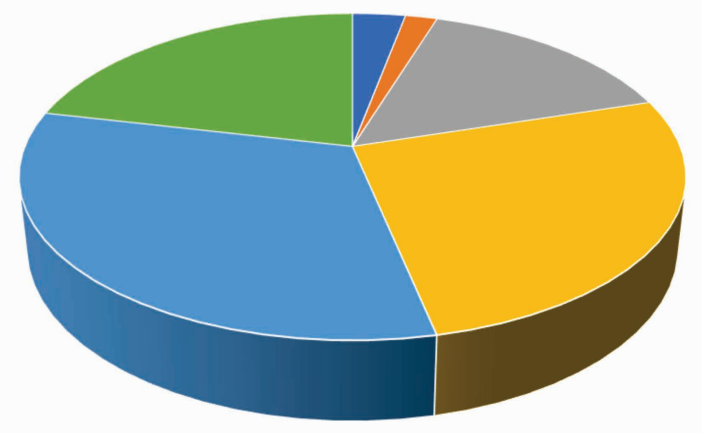

\footnotetext{
$\square$ Bimaxillary $\square$ Mandible right side $\square$ Maxillary right side $\square$ Mandible $\square$ Mandible left side $\square$ Maxillary left side
}

FIGURE 8. Location by common type of gum hyperplasia
TABLE 9. Common type of gum hyperplasia by gender

\begin{tabular}{|l|r|l|l|}
\hline & $\begin{array}{l}\text { Common type of } \\
\text { gum hyperplasia }\end{array}$ & $\begin{array}{l}\text { Other types of } \\
\text { gum hyperplasia }\end{array}$ & P value \\
\hline Females & 96 & 5 & \\
\cline { 1 - 3 } Males & 67 & 4 & 0.9999 \\
\cline { 1 - 3 } Total & 163 & 9 & \\
\hline
\end{tabular}

The Fisher test, $\mathrm{p}>0.05$, showed that there is no statistically significant association between gender and common type of gum hyperplasia. Thus, we conclude that the patient's gender does not influence the appearance of common type of gum hyperplasia (tables 8 and 9, figures 8 and 9).

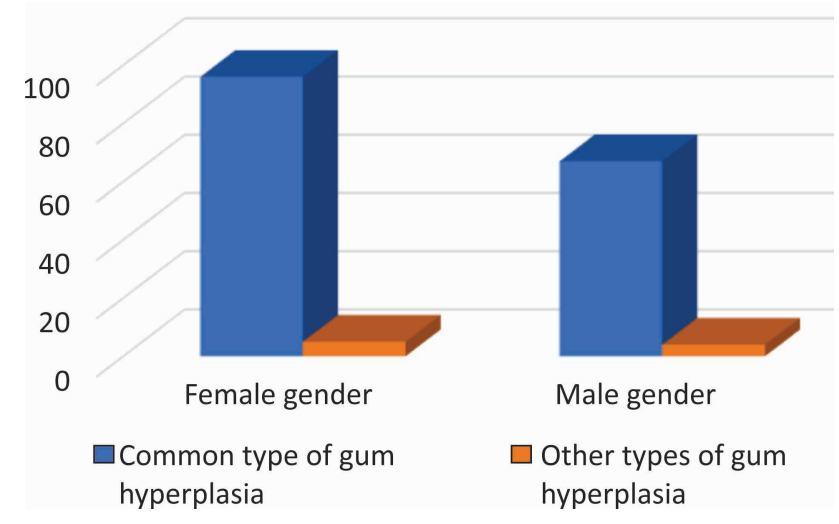

FIGURE 9. Common type of gum hyperplasia by gender

It is very interesting that females are more affected compare with males, probable by structure of the thin gingival biotype and some hormonal influence.

The Mann Whitney test, $\mathrm{p}<0.05$, showed that there was a statistically significant difference between the median ages in subjects with and without gingival hyperplasia. In medical terms, we conclude that the age of patients influences the appearance of hyperplastic lesions. 
TABLE 10. Common type of gum hyperplasia by age

\begin{tabular}{|l|r|r|r|}
\hline & $\begin{array}{l}\text { Average gingival hyperplasia } \pm \\
\text { standard deviation (Median) }\end{array}$ & $\begin{array}{l}\text { Without Average gingival hyperplasia } \pm \\
\text { standard deviation (Median) }\end{array}$ & P value \\
\hline Age & $58.96 \pm 19.66(65.00)$ & $43.22 \pm 21.21(51.00)$ & $\mathbf{0 . 0 2 4 3}$ \\
\hline
\end{tabular}

TABLE 11. Common type of gum hyperplasia by etiology

\begin{tabular}{|l|r|}
\hline \multicolumn{1}{|c|}{ Etiology } & $\begin{array}{l}\text { Common type of gum } \\
\text { hyperplasia }\end{array}$ \\
\hline Orthodontic treatment & 21 \\
\hline Local irritant factor & 117 \\
\hline Genetic & 0 \\
\hline Eruptive hyperplasia & 1 \\
\hline Decubitus lesion & 20 \\
\hline Recurrent & 2 \\
\hline $\begin{array}{l}\text { Chronic treatment with } \\
\text { immunosuppressants }\end{array}$ & 1 \\
\hline Pregnancy tumor & 1 \\
\hline Total & 163 \\
\hline
\end{tabular}

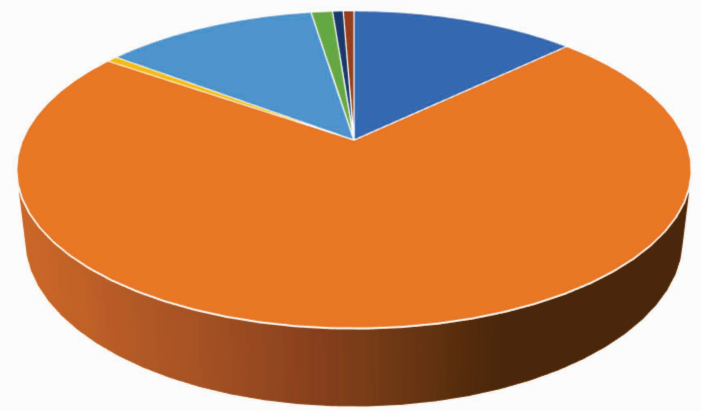

$\square$ Orthodontic treatment

- Local irritant factor

a Genetic

$\square$ Decubitus lesion

- Chronic treatment with immunosuppressants

口Eruptive hyperplasia

$\square$ Recurrent

- Pregnancy tumor

FIGURE 10. Common type of gum hyperplasia by etiology

Analyzing patients with a commom type of gum hyperplasia from the point of view of the etiology of the hyperplastic lesion, we observe the first place is occupied by the local irritative etiology followed by the orthodontic iatrogenic one and the decubitus lesion (table 10, figure 10).

\section{DISCUSSIONS}

The periodontal is composed of all tissues that provide the retention and support of teeth in the jaw bones, tissues that are in complete anatomical and functional interdependence (7). Gingival tissue is a protective barrier for deep structures from harmful factors in the oral cavity environment; once damaged, the tooth becomes susceptible to destruction and even loss from the arch. In modern society, periodontal disease can start as a result of poor oral hygiene, as a consequence of the exaggerated application of oral-dental hygiene methods, which cause damage to the gum, or due to trauma from orthodontic therapy (9-11).

Orthodontic therapy with fixed appliance shall be indicated after a correct evaluation of periodontal tissues, quantification of periodontal indices and detection of risk factors. Orthodontic treatments generally lead to improved interdental relationships, but also iatrogenic effects such as hyperplasia or gum-receptor may occur, especially in adults with periodontal disorders in the past. Gingival hyperplasia also occurs following an untimely orthodontic treatment when the gum is subject to stretch and the degree of keratinization is reduced. In the case of lower incisal gum, in patients with mandible prognathism, hyperplasia occurs due to both the position of the teeth and the thin tissue layer. The phenomenon often arises from orthodontic treatment of compensating mandible position by the lingual tilt of lower incisors, also conditioned by a thin gum type. Within the gingival biotype, the thickness of the keratinized gum is an important prognosis factor (Figure 11).

These observations determined Levin to develop the radiographic supporting bone index (RRBI - radiographic supporting bone index), which expresses the difference between the width of the alveolar bone measured at $2-3 \mathrm{~mm}$ apical by the enamel-cement junction and the tooth at the same level $(12,13)$.

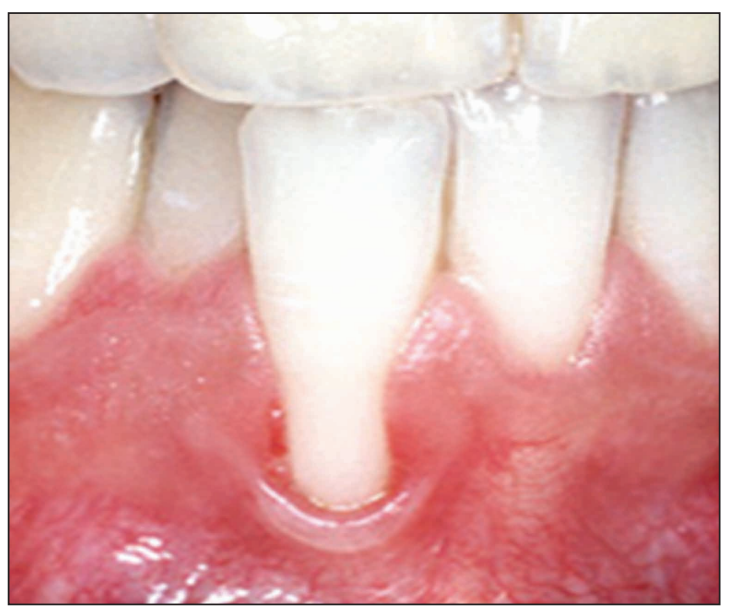

FIGURE 11. Gingival hyperplasia 


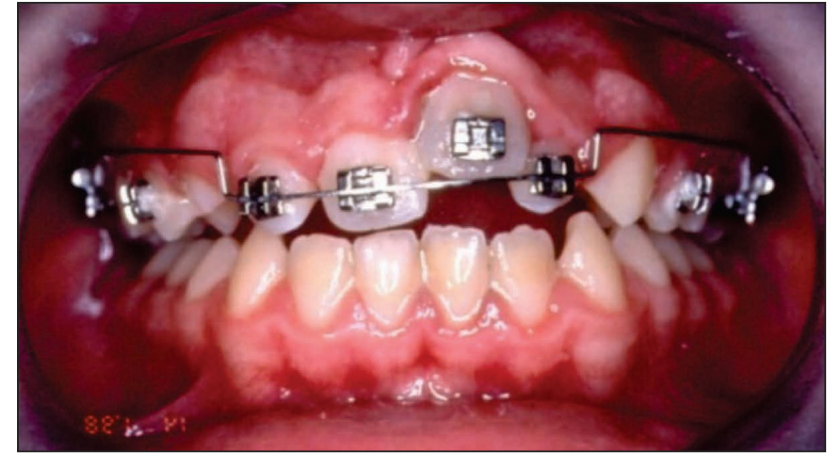

FIGURE 12. Gingival hyperplasia during fixed treatment

The lower the value of this index, the greater the risk of gum hyperplasia. Also, when analyzing the descriptive statistical data of this clinical-statistical study, it is observed that gingival hyperplasia is generally occurring in adults, especially to females, and is affinity for right hemimaxilla, approx. $25 \%$ of patients have gingival hyperplasia produced by orthodontic treatments and prostheses (figure 12).

The metabolic activity of the periodontal tissues is also influenced by their physiological characteristics. Thus, an important factor that needs to be considered regarding the periodontal tissue remodeling during orthodontic therapy is the patient's age. The alveolar bone density grows together with age and will thus generate a different biological response in teen/adult patients relative to children. Although the relation between local factors and orthodontic forces is not fully understood, it appears that there is a causality relation between the direction and nature of these forces and the changes in the blood flux, therefore having the inflammation mediators directly influenced, emphasized at the periodontal tissue and the gingival sulcus level $(4,13)$.

There are controversies in the literature with regard to the necessary dimension of the keratinized gingiva required to maintain gingival health. Loe and Lang (1972), cited by (14), consider that a strip of $2 \mathrm{~mm}$ of keratinized gingiva is required, whereas other authors $(15,16)$ debate this fact, suggesting that gingival health and also be maintained at a width smaller than $1 \mathrm{~mm}$ of the keratinized gingiva. The teeth situated in buccal position or buccally inclined may be accompanied by bone dehiscence, brittle soft tissue, being also possibly accompanied by gingival recessions that pre-existed the orthodontic treatment $(15,16)$.

\section{CONCLUSIONS}

These types of lesions represent a ratio of $2 / 1$ in favor of the females, which means that the esthetic requirements of the females are much higher compared to the males.

The presence of dento-maxillary anomalies and fixed orthodontic appliances increase the risk of periodontal suffering, especially the recession ang gingival hyperplasia.

Concerning the etiological factors, the most frequent is local irritant of gingival tissue, followed by orthodontic treatment.

The frequent localization is maxillary right side, followed by mandible left side.

Orthodontic therapy should be indicated after a correct evaluation of periodontal tissues, quantification of periodontal index and detection of risk factors.

Conflict of interest: none declared Financial support: none declared

\section{REFERENCES}

1. Hazan-Molina H, Levin L, Einy S, Aizenbud D. Aggressive periodontitis diagnosed during or before orthodontic treatment. Acta Odontol Scand. 2013 Sep;71(5):1023-31.

2. Fujii T, Kitaura H, Kimura K, Hakami ZW, Takano-Yamamoto T. IL-4 inhibits TNF-a-mediated osteoclast formation by inhibition of RANKL expression in TNF- $\alpha$-activated stromal cells and direct inhibition of TNF-a-activated osteoclast precursors via a T-cell-independent mechanism in vivo. Bone. 2012 Oct;51(4):771-80.

3. Levin L, Einy S, Zigdon H, Aizenbud D, Machtei EE. Guidelines for periodontal care and follow-up during orthodontic treatment in adolescents and young adults. J Appl Oral Sci. 2012 Jul-Aug; 20(4):399-403.

4. Agudio G, Nieri M, Rotundo R, Cortellini P, Pini Prato G. Free gingival grafts to increase keratinized tissue: a retrospective

long-term evaluation (10 to 25 years) of outcomes. J Periodontol. 2008 Apr;79(4):587-94.

5. Gong Y, Lu J, Ding X. Clinical, microbiologic, and immunologic factors of orthodontic treatment-induced gingival enlargement. $\mathrm{Am} \mathrm{J}$ Orthod Dentofacial Orthop. 2011 Jul;140(1):58-64.

6. Borghetti A, Monnet-Corti V. Chirurgie plastique parodontale (2ème edition). Paris: Editions CdP, 2008.

7. Dumitriu HT, Dumitriu S, Dumitriu AS. Parodontologie. Bucureşti: Editura Viaţa Medicală Românească, 2009.

8. Nakib N, Ashrafi SS. Drug-induced gingival overgrowth. Dis Mon. 2011 Apr;57(4):225-30.

9. Arora PC, Kaur Jasleen, Kaur Jasmine, Arora A. Teledentistry: An innovative tool for the underserved population. Digit Med. 2019;5(1):6-12. 
10. Grzibovskis M, Urtane I, Pilmane M. Specific signaling molecule expression in periodontal ligaments in different age groups: pilot study. Stomatologija. 2011;13(4):117-22.

11. Gorbunkova A, Pagni G, Brizhak A, Farronato G, Rasperini G. Impact of Orthodontic Treatment on Periodontal Tissues: A Narrative Review of Multidisciplinary Literature. Int J Dent. 2016; 2016:4723589.

12. Bhatsange A, Shende A, Deshmukh S, Japatti S. Management of fenestration using bone allograft in conjunction with platelet-rich fibrin. J Indian Soc Periodontol. 2017 Jul-Aug;21(4):337-340.

13. Tepedino M, Franchi L, Fabbro $O$, Chimenti C. Post-orthodontic lower incisor inclination and gingival recession-a systematic review. Prog Orthod. 2018 Jun 18;19(1):17.
14. Schrott AR, Jimenez M, Hwang JW, Fiorellini J, Weber HP. Five-year evaluation of the influence of keratinized mucosa on peri-implant soft-tissue health and stability around implants supporting full-arch mandibular fixed prostheses. Clin Oral Implants Res. 2009 Oct;20(10):1170-7.

15. Coşkun I, Kaya B. Appraisal of the relationship between tooth inclination, dehiscence, fenestration, and sagittal skeletal pattern with cone beam computed tomography. Angle Orthod. 2019 Jul;89(4):544-551.

16. Evans M, Tanna NK, Chung CH. 3D guided comprehensive approach to mucogingival problems in orthodontics. Semin Orthod. 2016;22(1):52-63. 